\title{
Phytic Acid- an AntiNutrient Nutraceutical in Ethnic Vegetables Growing Wildly in Tribal Regions of Bangladesh
}

\author{
Amena Begum", Mahbuba Kawser ${ }^{2, ~ *, ~ S a m i a ~ S a m s ², ~ P a r v e e n ~ B e g u m ², ~ M a k s u d a ~ K h a t u n ~}{ }^{2,3}$, \\ Shabnam Mostafa ${ }^{2}$, Muhammad Akhtaruzzaman ${ }^{2}$, Sheikh Nazrul Islam ${ }^{2}$ \\ ${ }^{1}$ Samorita Hospital Limited, Panthapath, Dhaka, Bangladesh \\ ${ }^{2}$ Institute of Nutrition and Food Science, University of Dhaka, Dhaka, Bangladesh \\ ${ }^{3}$ Depart of Botany, University of Dhaka, Dhaka, Bangladesh
}

Email address:

smritymona@gmail.com (A. Begum),mahbubakawser@gmail.com(M. Kawser), samiasams12@yahoo.com(S. Sams), pbegum963@gmail.com (P.Begum),kmaksuda@yahoo.com(M. Khatun), a_rumky@yahoo.com (S. Mostafa), makhtar@du.ac.bd (M. Akhtaruzzaman),Sheikhnazrul09@gmail.com (S. Nazrul Islam)

${ }^{*}$ Corresponding author

\section{To cite this article:}

Amena Begum, Mahbuba Kawser, Samia Sams, Parveen Begum, Maksuda Khatun, Shabnam Mostafa, M. Akhtaruzzaman, Sheikh Nazrul Islam. Phytic Acid- an AntiNutrient Nutraceutical in Ethnic Vegetables Growing Wildly in Tribal Regions of Bangladesh. Journal of Diseases and Medicinal Plants. Vol. 6, No. 1, 2020, pp. 16-21. doi: 10.11648/j.jdmp.20200601.13

Received: January 4, 2020; Accepted: January 16, 2020; Published: January 31, 2020

\begin{abstract}
Phytate has nutraceutical property and scores of potential health benefits in spite of undesirable anti nutrient property. This article investigated phytic acid content in a wide variety of ethnic vegetables growing wildly in tribal regions of Bangladesh. The study was conducted on thirty four rare ethnic vegetables comprising 26 leafy and 8 non-leafy vegetables. A multiregional sampling plan was employed to collect representative samples. The vegetable were collected from weekly markets at Rangamati, Bandarban, Mymensing, Gazipur and Madhupur. The vegetable samples collected were identified and certified by a taxonomist of the Department of Botany, University of Dhaka. After taking the vegetables to the lab, the taxonomist confirmed their English and Scientific names. For the estimation of moisture $5 \mathrm{~g}$ cleaned, air-dried, chopped and well mixed samples were taken and the remainder was first dried in the sun, then in an electric dryer. Dried samples were ground in a mechanical grinder, kept in auto seal packs and stored in clean desiccators to avoid further moisture gain. These samples (analytes) were ready for further analysis. Phytic acid was determined by Spectro-photometric method. The values reported were the means of three replicates. Two leafy and two non-leafy vegetables could not be identified taxonomically. Overall Phytic acid content in both leafy and non leafy vegetables was ranged from $3.10 \pm 0.07$ to $72.18 \pm 0.56 \mathrm{mg}$ per $100 \mathrm{~g}$ edible portion. In leafy vegetables, Indian acalypha (Acalypha indica) contained the lowest content of phytic acid, while in the non leafy lowest phytic acid was present in the Greater Yam (Dioscorea alata). However, French/kidney bean (Vigna grahamiana), Bronze banana (Musa ornata), Yam (Dioscorea bulbifera), Lime (Citrus aurantifolia), Kamino (Caesalpinia digyna), Amsurothi, and tamarind leaves (Tamarindus indica) contained higher amount (ranged from $21.48 \pm 0.29$ to $72.18 \pm 0.56 \mathrm{mg}$ per $100 \mathrm{~g}$ edible portion) of phytic acid followed by moderate amount of phytate contents in smartweed (Ampelygonum chinense), Greater galangal (Alpinia nigra), Duggal fiber tree leaves (Sarcochlamys pulcherrima) and Ghima leaves (Polycarpan prostratum) (ranged from $15.8 \pm 0.81$ to $19.49 \pm 0.79 \mathrm{mg}$ per $100 \mathrm{~g}$ edible portion). Some other vegetables also had a lower phytic acid content. These ethnic rare vegetables which are rich in phytic acid and other nutrients have both nutraceutical and antioxidant potential could cure future environment and stress induced non communicable chronic diseases.
\end{abstract}

Keywords: Phytic Acid, Anti Nutrient, Nutraceutical, Ethnic Vegetables, Tribal Region, Bangladesh

\section{Introduction}

Anti nutrients are found in grains, beans, legumes and nuts, but can also be found in leaves, roots and fruits of certain varieties of plants. The major anti nutrient found in plant-based foods is phytates, tannins, lectins, oxalates etc. Anti nutrients reduce the availability of nutrients and cause growth inhibition. Phytic acid is a free-acid form of myo- 
inositol hexakisphosphoric acid (InsP6) and constitutes 1-5\% by weight of most cereals, nuts, legumes, and oil seeds. The presence of phytic acid in seeds makes remarkable longevity; some plant seeds may remain viable for up to 400 years [1]. Phytic acid binds with iron and produces ferric phytate, which acts as an antioxidant and prevents oxidative damage, especially of unsaturated fatty acids of seeds [2].

Phytic acid has a strong affinity for monovalent, divalent and polyvalent cations, and produces metal phytate complexes [2], which accumulates in the seeds during the ripening period [3]. Phytic acid has a strong ability to chelate multivalent metal ions, specially zinc, calcium and iron. The binding can result in very insoluble salts with poor bioavailability of minerals [4]. Phytate is best known as antinutrient, which makes deleterious effects on absorption of nutrients and micronutrients. Phytate affects bioavailability of $\mathrm{Zn}^{2+}, \mathrm{Fe}^{2+} \beta^{3+}, \mathrm{Ca}^{2+}, \mathrm{Mg}^{2+}, \mathrm{Mn}^{2+}$, and $\mathrm{Cu}^{2+}$. The phytic acid is associated with bran (rich in dietary fiber); some brans contain over $5 \%$ phytic acid, therefore, increased consumption of high fiber foods results in high consumption of phytic acid. Hence, high consumption of phytate containing food results in mineral deficiency, which may lead to a nutritional deficiency [5], particularly deficiency of zinc and iron. Phytate also affects carbohydrate, fat and protein digestibility as well as nutritional values [6].

In addition to harmful health effect, some anti nutrients have been reported to have beneficial health effects. Phytate, lectins, tannins, saponins, amylase inhibits or a low concentration reduces the blood glucose and insulin responses to carbohydrate foods and/or plasma cholesterol and triglycerides, and has also been reported to reduce various types of cancer risks, even inhibit replication of HIV $[3,6,7]$. Dietary phytate, owing to its antioxidant potential, has been reported to prevent many stress induced non communicable chronic diseases such as diabetes mellitus, cardiovascular complications, renal lithiasis, protect against a variety of cancers $[6,8]$. Phytic acid is the major phosphorus storage compound of most seeds, cereal grains and vegetables (accounts for $>70 \%$ of the total phosphorus), which is present in the form of phytin, the calcium magnesium salt of inositol hexaphosphoric acid, a widely recommended phosphorous source in human nutrition $[3,6$, 8]. Thus anti-nutrients can be considered as anti-nutritional factors with negative effects or non-nutritive compounds with positive effects on health [3]. However, information on the dosage for humans for eliciting beneficial effects is limited [6]. In view of anti nutrient and nutraceutical potential, the present study investigated phytic acid content in a wide variety of ethnic vegetables growing wildly in tribal regions of Bangladesh.

\section{Materials and Methods}

\subsection{Sampling Protocol}

The study was conducted on thirty fourlocally consumed rare ethnic vegetables (26 leafy and 8 non-leafy). A multiregional sampling plan was employed to collect representative samples. The vegetable were collected from weekly markets at Rangamati, Bandarban, (hilly tribal regions), and Mymensing, Gazipur and Madhupur (plane tribal regions). Two samples for each of the vegetables of approximately $1.5 \mathrm{~kg}$ were purchased from every market, which were pooled together to make an analyte; triplicate samples for each analyte were analyzed. During transportation to the lab, the samples were water sprayed and packed into fresh plastic poly bags.

\subsection{Identification of Vegetable Samples}

The vegetable samples collected were taxonomically identified and certified by a plant taxonomist, Professor Dr. Mohammed Abul Hassan, Department of Botany, University of Dhaka. After taking the vegetables to the lab, the taxonomist confirmed their English and Scientific names (Table 1).

\subsection{Preparation of the Analytes}

Receiving the samples in the laboratory, vegetables were first rinsed with tape water followed by washing with distilled water, then gently swabbed with tissue paper and air dried. Separation of the edible and non-edible portion was done carefully. The cleaned air-dried samples were diced or cut into small pieces using a cleaned stainless knife on a cleaned plastic cutting board. Hand gloves were used throughout the processing. The diced food samples were taken to a stainless steel bowl and mixed by a plastic spatula. Some freshly chopped samples were wrapped with aluminum foil and put into the Ziploc brand plastic freezer bags. For the estimation of moisture $5 \mathrm{~g}$ samples were taken from the chopped weighted vegetables. The remainder was first dried in the sun, then in an electric dryer. Dry samples were ground in a mechanical grinder, kept in auto seal pack and stored in clean desiccators to avoid further moisture gain. These samples were ready for further analysis.

\subsection{Reagents}

The analytical grade trichloro acetic acid, ferric chloride, sodium sulphate, sodium hydroxide, nitric acid, potassium thiocyanate, ferric nitrate were purchased from Merck (Darmstadt, Germany).

\subsection{Determination of Phytic Acid}

Phytic acid was determined by spectro-photometric method as described by Wheeler and Ferrel [9]. Phytic acid in vegetable was extracted with $3 \%$ trichloro acetic acid and precipitating it as ferric Phytate, which was then converted to ferric hydroxide and soluble sodium phytate by adding sodium hydroxide and boiling it. The precipitate was then dissolved in diluted acid and the iron content determined colorimetrically. A reagent blank was run with each set of samples, $\mathrm{Fe}\left(\mathrm{NO}_{3}\right)_{3}$ standards were prepared and absorbance was read with the spectrophotometer at $750 \mathrm{~nm}$ (UV-1201, UV-VIS, Spectrophotometer, Shimadzu Corporation, Japan). 
By these a standard curve was constructed from which the iron concentrations were obtained. The phytate content was then calculated from the iron concentration by assuming a constant (Fe: P) molecular ratio of (4:6) in the precipitate. The values reported were the means of three replicate samples.

\subsection{Statistical Analyses}

After laboratory analysis the results were entry into Microsoft excel sheet. The values expressed as mean \pm standard deviation (Mean $\pm \mathrm{SD}$ ), were the means of three replicate samples.

Table 1. List of the Ethnic vegetables investigated.

\begin{tabular}{|c|c|c|c|c|}
\hline & Local name & English name & Scientific Name & Family \\
\hline \multicolumn{5}{|c|}{ Leafy Vegetables } \\
\hline 1 & Kochi aam pata & Tender Mango leaf & Magnifera indica $\mathrm{L}$. & Anacardiaceae \\
\hline 2 & Kamino & Teri Pods leaves & Caesalpinia digyna Rottler. & Caesalpiniaceae \\
\hline 3 & Moroi shak & Funnel leaves & Foeniculum vulgare L. & Apiaceae \\
\hline 4 & Amsurothi & Not known & Not known & $\mathrm{Na}$ \\
\hline 5 & Noyalongbikrongi & Trailing Smartweed. & Ampelygonum chinense & Polygonaceae \\
\hline 6 & Monjori & Not known & Not Known & $\mathrm{Na}$ \\
\hline 8 & Missayanu/jangli shak & Duggal fiber tree leaves & Sarcochlamys pulcherrima Gaudich. & Urticaceae \\
\hline 9 & Felong dal shak & Common Bean leaves & Phaseolus vulgaris L. & Fabaceae \\
\hline 10 & Gaiboma/Ghima leaves & Not known & Polycarpan prostratum (Forssk.) Asch. & Caryophyllaceae \\
\hline 11 & Chikipung & Rosy/bladder Dock & Rumex vesicarius $\mathrm{L}$. & Polygonaceae \\
\hline 12 & Ambush & Lettuce-Leaf Blumea & Blumea laceraL. & Asteraceae \\
\hline 13 & Mrolapiong & Bitter cassava/Tapioka & Manihot esculenta Gantz. & Euphorbiaceae \\
\hline 14 & Projukti pata & Arrow leaf pondweed & Monochoria hastata (L.) Solms. & Pontederiaceae \\
\hline 16 & Katoldingi & Arum & Lasia spinosa (L.) Thw. & Araceae \\
\hline 17 & Kasani & Heartshape False & Monochoria vaginalis (Burm. f.) C. Presl. & Pontederiaceae \\
\hline 18 & Saimya & Sour Lime & Citrus aurantifolia (Christm.) Swingle & Rutaceae \\
\hline 19 & Balapata & Pouzolzia & Pouzolzia hirta (Blume.) & Urticaceae \\
\hline 20 & Khudemanik & Thankuni leaves & Centella asiatica (L.) Urban & Apiaceae \\
\hline 21 & Bon palong & Bitter dock & Rumex maritimus L. & Polygonaceae \\
\hline 22 & Muktajhuri & Indian acalypha & Acalypha indica $\mathrm{L}$. & Euphorbiaceae \\
\hline 23 & Roktodrone & Red verticulia/honeyweed & Leonurus sibiricus L. & Lamiaceae \\
\hline 24 & Jolpaipata & Indian olive leaves & Elaeocarpus Roxb. & Elaeocarpaceae \\
\hline 25 & Sadakoroi & Labbec tree & Albizia procera (Roxb.) Benth. & Fabaceae \\
\hline 26 & Tetulpata & Tamarind leaves & Tamarindus indica $\mathrm{L}$. & Caesalpiniaceae \\
\hline \multicolumn{5}{|c|}{ Non Leafy Vegetables } \\
\hline 27 & Fala/tara/jongly ginger & Greater/False galangal & Alpinia nigra (Gaertn.) & Zingiberaceae \\
\hline 28 & Forash dal & Kidney/French bean & Vigna grahamiana & Fabaceae. \\
\hline 29 & Kiokokro & Dried sea weed & Not Known & $\mathrm{Na}$ \\
\hline 30 & Kortolik & Not known & Not Known & $\mathrm{Na}$ \\
\hline 33 & Sornolota/torulota & Dodder & Cuscuta reflexa Roxb. & Cruscutaceae \\
\hline 34 & Jongli kola & Bronze banana & Musa ornata Roxb. & Musaceae \\
\hline
\end{tabular}

$\mathrm{Na}=$ not applicable.

Table 2. Phytic acid content in ethnic vegetables

\begin{tabular}{|c|c|c|c|c|}
\hline & \multirow{2}{*}{ Local Name } & \multirow{2}{*}{ English Name } & \multirow{2}{*}{ Scientific Name } & \multirow{2}{*}{$\begin{array}{l}\text { Phytic acid }(\mathrm{mg} / 100 \mathrm{~g} \mathrm{dw}) \\
\text { Mean } \pm \text { SD }\end{array}$} \\
\hline & & & & \\
\hline \multicolumn{5}{|c|}{ Leafy vegetables } \\
\hline 1 & Kochi aam pata & Tender Mango leaf & Mangifera indica $\mathrm{L}$. & $10.51 \pm 0.58$ \\
\hline 2 & Kamino & Teri pods leaves & Caesalpinia digyna Rottler. & $28.53 \pm 0.82$ \\
\hline 3 & Moroi shak & Funnel leaves & Foeniculum vulgare $\mathrm{L}$. & $11.81 \pm 0.93$ \\
\hline 4 & Amsurothi & Not known & Not known & $22.93 \pm 0.33$ \\
\hline 5 & Noyalongbikrongi & Trailing Smartweed. & Ampelygonum chinense & $16.55 \pm 0.38$ \\
\hline 7 & Yangfo & Banyan Tree leaves & Ficus benghalensis $\mathrm{L}$. & $10.66 \pm 0.66$ \\
\hline 8 & Missayanu/jangli shak & Duggal fiber tree leaves & Sarcochlamys pulcherrima Gaudich. & $16.31 \pm 0.28$ \\
\hline 9 & Felong dal shak & Common Bean leaves & Phaseolus vulgaris L. & $14.34 \pm 1.09$ \\
\hline 10 & Gaiboma/Ghima leaves & Not known & Polycarpan prostratum (Forssk.) Asch. & $19.49 \pm 0.79$ \\
\hline 11 & Chikipung & Rosy/bladder Dock & Rumex vesicarius $\mathrm{L}$. & $7.32 \pm 0.73$ \\
\hline 12 & Ambush & Lettuce-Leaf Blumea & Blumea lacera $\mathrm{L}$. & $12.82 \pm 0.85$ \\
\hline 13 & Mrolapiong & Bitter Cassava/Tapioka & Manihot esculenta Gantz. & $12.53 \pm 0.73$ \\
\hline
\end{tabular}




\begin{tabular}{|c|c|c|c|c|}
\hline & \multirow{2}{*}{ Local Name } & \multirow{2}{*}{ English Name } & \multirow{2}{*}{ Scientific Name } & \multirow{2}{*}{$\begin{array}{l}\text { Phytic acid }(\mathrm{mg} / 100 \mathrm{~g} \mathrm{dw}) \\
\text { Mean } \pm \text { SD }\end{array}$} \\
\hline & & & & \\
\hline 15 & Khoro pata/marmaria & Not known. & Cissus repens Lam. & $8.48 \pm 0.69$ \\
\hline 16 & Katoldingi & Arum & Lasia spinosa (L.) Thw. & $12.09 \pm 0.79$ \\
\hline 17 & Kasani & Heartshape False & Monochoria vaginalis (Burm. f) C. Presl. & $8.52 \pm 0.48$ \\
\hline 18 & Saimya & Sour Lime & Citrus aurantifolia (Christm.) Swingle & $31.39 \pm 0.83$ \\
\hline 19 & Bala pata & Pouzolzia & Pouzolzia hirta (Blume.) & $5.09 \pm 0.66$ \\
\hline 20 & Khudemanik & Thankuni leaves & Centella asiatica (L.) Urban & $4.27 \pm 0.03$ \\
\hline 21 & Bon palong & Bitter dock & Rumex maritimus L. & $9.01 \pm 0.13$ \\
\hline 22 & Muktajhuri & Indian acalypha & Acalypha indica L. & $3.10 \pm 0.07$ \\
\hline 23 & Roktodrone & Red verticulia/honeyweed & Leonurus sibiricus L. & $8.02 \pm 0.17$ \\
\hline 24 & Jolpai pata & Indian olive leaves & Elaeocarpus Roxb. & $\mathrm{Nd}$ \\
\hline 25 & Sadakoroi & Labbec tree & Albizia procera (Roxb.) Benth. & $6.64 \pm 0.14$ \\
\hline 26 & Tetul pata & Tamarind leaves & Tamarindus indica $\mathrm{L}$. & $21.48 \pm 0.29$ \\
\hline \multicolumn{5}{|c|}{ Non-Leafy vegetable } \\
\hline 27 & Fala/tara/jongly ginger & Greater/False galangal & Alpinia nigra (Gaertn.) & $15.8 \pm 0.81$ \\
\hline 28 & Forash dal/Rajma & Kidney/French bean & Vigna grahamiana & $72.18 \pm 0.56$ \\
\hline 29 & Kiokokro & Dried sea weed & Not Known & $8.21 \pm 0.29$ \\
\hline 30 & Kortolik & Not known & Not Known & $12.48 \pm 1.12$ \\
\hline 31 & Mo alu & Yam & Dioscorea bulbifera $\mathrm{L}$. & $25.21 \pm 0.89$ \\
\hline 32 & Rangajhumalu & Purple/Greater Yam & Dioscorea alata $\mathrm{L}$. & $6.50 \pm 0.32$ \\
\hline 33 & Sornolota & Dodder & Cuscuta reflexa Roxb. & $\mathrm{Nd}$ \\
\hline 34 & Jongli kola & Bronze banana & Musa ornata Roxb. & $36.52 \pm 0.11$ \\
\hline
\end{tabular}

$\mathrm{Nd}=$ not done, $\mathrm{dw}=$ dried weight.

\section{Results}

A total of 34 ethnic vegetables comprising 26 leafy and 8 non-leafy vegetables growing wildly in the tribal regions, and regularly consumed by the ethnic people were investigated for their phytic acid content. However, two leafy and two nonleafy vegetables could not be identified taxonomically. Overall Phytic acid content in both leafy and non leafy vegetables ranged from $3.10 \pm 0.07$ to $72.18 \pm 0.56 \mathrm{mg}$ per $100 \mathrm{~g}$ edible portion (Table 2). In leafy vegetables, Indian acalypha (Acalypha indica) contained the lowest content of phytic acid, while in the non leafy lowest phytic acid was present in the Greater Yam (Dioscorea alata). However, French bean (Vigna grahamiana), Bronze banana (Musa ornata), Yam (Dioscorea bulbifera), Lime (Citrus aurantifolia), Kamino (Caesalpinia digyna), Amsurothi, and tamarind leaves (Tamarindus indica) contained higher amount $(21.48 \pm 0.29$ to $72.18 \pm 0.56 \mathrm{mg}$ per $100 \mathrm{~g}$ edible portion) of phytic acid followed by moderate amount of phytate contents in smartweed (Ampelygonum chinense), Greater galangal (Alpinia nigra), Duggal fiber tree (Sarcochlamys pulcherrima) and Ghima leaves (Polycarpan prostratum)(ranged from $15.8 \pm 0.81$ to $19.49 \pm 0.79 \mathrm{mg}$ per $100 \mathrm{~g}$ edible portion). Some other vegetables also had a lower phytic acid content.

\section{Discussion}

The recently prepared food composition tables and database for Bangladesh [10-12] did not have any data on phytic acid or phytate. Leafy vegetable contains a very low content of phytic acid but its data is sparse. No phytic acid data has yet been reported or available for ethnic foods. This makes it difficult to discuss or compare these data. However, some phytic acid data for common similar leafy vegetable $[6$, $7,13,14]$ were found to be less or comparable to the present data. Phytate content reported to be very higher in various legumes [14] than French/kidney bean (Vigna grahamiana) of this study while lower amount of phytate in kidney bean and sesame seeds was reported [6]. It is well documented that diacotyledons seeds such as legumes, nuts and oilseeds have huge phytic acid and are found closely concentrated with protein fraction of these foods [15]. Study also reported [16] higher content of phytic acid in Yam (Dioscorea alata) than ours. However, Anti nutrients in vegetables, whole grains, legumes and nuts are a concern only when a person's diet is composed exclusively of uncooked plant foods [6, 14]. Processing techniques, such as soaking, germination, malting and fermentation, reduce phytate content by increasing activity of naturally present phytase (phytic acid degrading enzyme). Also, supplementation of phytase in diets results in increase in mineral absorption [6].

In spite of undesirable anti nutrient property, phytate has scores of potential health benefits [6]. Its antioxidant property, especially ferric phytate, makes protection against many cancers $[6,7]$. It acts as a novel broad spectrum anti neoplastic agent $[7,15,18]$. Phytate boosts immunity against carcinogenic threat. It has been reported effective against cardiovascular complications including hyper lipidemia, anti platelet activity, and against diabetes mellitus [6]. Phytate, even, claims to inhibit HIV-1 replication in $\mathrm{T}$ cell line. Furthermore, phytate prevents formation of kidney stones [6, 19] and has anti microbial activity [20]. In addition to anti nutrient property, Phytate has much diverse therapeutic potential [6]. Intake of nutraceutical ethnic vegetables like French bean (Vigna grahamiana), Bronze banana (Musa ornata), Yam (Dioscorea bulbifera), Lime (Citrus aurantifolia), Kamino (Caesalpinia digyna), Amsurothi, and tamarind leaves (Tamarindus indica) may alleviate many chronic diseases. Moreover, study showed [21] ethanol extract of Kamino (Caesalpinia digyna) roots exhibits 
significant anti anxiety activity compared to diazepam; leaf extracts of Greater galangal (Alpinia nigra) possessed profound cytotoxic and analgesic and moderate antibacterial activities [22]. Antimicrobial activities of the leaves extracts of Duggal fiber tree (Sarcochlamys pulcherrima) [23] and Tamarindus indica [24] were also reported. However, these phytic acid containing ethnic vegetables could enrich the existing database and food composition table of Bangladesh and others as well as consumption of these leafy and non leafy vegetables have many positive and beneficial health effects. Food processing or adding exogenous phytate degrading enzyme or phytase can minimize the negative effects of phytate and boosts the antioxidant, anti carcinogen, immune and therapeutic potential of phytatic acid.

\section{Conclusion}

Ethnic rare vegetables investigated in this study are consumed regularly by the ethnic minorities of Bangladesh, which could be the cheapest source of nutraceuticals, antioxidant, anti carcinogens and immune boosting agents to the general population of Bangladesh as well as to the other developing parts of the world. Consumption of these vegetables is likely to provide therapeutic potential against environment and stress induced NCDs or non communicable chronic diseases (e.g. variety of cancers, diabetes mellitus, atherosclerosis, coronary heart disease). The dephosphorylation of phytate occurs during food processing (e.g. cooking, soaking, malting, ensiling and drying by increasing the activity of naturally present phytase, phytatedegrading enzyme in plant and microbes) and/or by adding exogenous phytase results in the improvement of the bioavailability of essential minerals, potential way to reduce the risk of mineral deficiency among populations, mainly in developing countries, consuming unrefined cereals or pulses as a major diet. In addition, the beneficial health effects of phytate could be more significant for the populations in developed countries (as not suffering from mineral deficiencies) because of the higher incidence of colon cancer which is associated with higher fat and lower fiber-rich food intakes. More intensive studies are needed to obtain better insight about this.

\section{Acknowledgements}

Authors are thankful to the Ethnic people of Chittagong Hill Tracts and plain lands for cooperation in sample collection, identification of edible portions and naming of the locally produced rare vegetable samples.

\section{References}

[1] Owen RW, Weisgerber UM, Spiegelhalder B, Bartsch H. Faecalphytic acid and its relation to other putative markers of risk for colorectal cancer. Gut 1996, 38: 591-597. DOI: 10.1136/gut.38.4.591.
[2] Graf E, Eaton JW (1990). Antioxidant functions of phytic acid. Free Radical Biology and Medicine, Volume 8, issue 1, P 6169. https://doi.org/10.1016/0891-5849 (90) 90146-A.

[3] Gemede HF, NegussieRatta N. Antinutritional factors in plant foods: Potential healthbenefits and adverse effects. Int J Nutr Food Sci2014; 3 (4): 284-289. doi: 10.11648/j.ijnfs.20140304.18.

[4] Zhou JR, Erdman JV. (1995). Phytic acid in health and disease. CRC Critical Reviews in Food Science and Nutrition, 1995, 35 (6): 495-508.

[5] Gupta RK, Gangoliya SS, Singh NK. Reduction of phytic acid and enhancement of bioavailable micronutrients in food grains. J Food Sci Technol. 2015, 52 (2): 676-684. DOI: 10.1007/s13197-013-0978-y.

[6] Kumar V, Sinha AK, Makkar HPS, Becker K. Review Dietary roles of phytate and phytase in human nutrition: A review. Food Chemistry 2010, 120: 945-959. doi: 10.1016/j.foodchem.2009.11.052.

[7] Schlemmer U, Frølich W, Prieto RM, Felix Grases F. Review Phytate in foods and significance for humans: Food sources, intake, processing, bioavailability, protective role and analysis Mol. Nutr. Food Res. 2009, 53: S330-S375DOI: 10.1002/mnfr.200900099.

[8] McCance RA, Widdowson EM. Phytin in human nutrition. The Biochemical Department, King, s College Hospital. London. Biochem J. 1935, 29 (12): 2694-9. DOI: 10.1042/bj0292694.

[9] Wheeler EL, Ferrel RE. A method for phytic acid determination in wheat and wheat fractions. Western Regional Research laboratory, Agricultural resrarch service, USD department of Agriculture, Albany, California 94710. Cereal Chemistry 1971, 48 (3): 312-320. ISSN: 0009-0352Record Number: 19721492732.

[10] Islam SN, Khan MNI, Akhtaruzzaman M. A Food Composition Database for Bangladesh with Special reference to Selected Ethnic Foods. fpmu.gov.bd > sites > default > files > Final report, 2010.

[11] Islam SN, Khan MNI, Akhtaruzzaman M. Food Composition Tables and Database for Bangladesh with Special Reference to Selected Ethnic Foods. Edited by Md. Nazrul Islam Khan, Sheikh Nazrul Islam; Reviewed by Sagarmay Barua, INFS, DU; Palal Prokashoni, Shahbag, Dhaka, Bangladesh, 2012.

[12] Shaheen N, Rahim ATMA, Mohiduzzaman M, et al (2014). Food Composition Table for Bangladesh. www.nfpcsp.org.

[13] Alkarawi HH, Zotz G. Review article Phytic acid in green leaves. Plant Biology 2014, 16: 697-701. https://doi.org/10.1111/plb.12136.

[14] Popova A and Mihaylova D (2019). Antinutrients in Plantbased Foods: A Review. The Open Biotechnology Journal, 2019, Volume 13 69DOI: 10.2174/1874070701913010068, 2019, 13, 68-76.

[15] Sinha K, Khare V (2017). Review on: Antinutritional factors in vegetable crops. The Pharma Innovation Journal 2017; 6 (12): 353-358 www.thepharmajournal.com.

[16] Akalu Z K, Geleta S H (2017). Antinutritional Levels of Tubers of Colocasiaesculenta, L. Schott (Taro) and Dioscoreaalata (Yam) Cultivated in Ethiopia. J Nutr Food Sci 2017, 7: 2. DOI: 10.4172/2155-9600.1000585. 
[17] Fox CH, Eberl M. Phytic acid (IP6), novel broad spectrum anti-neoplastic agent: a systematic review. Complement Ther Med. 2002, 10 (4): 229-34. DOI: 10.1016/s0965-2299 (02) 00092-4.

[18] Norhaizan M E, Ng S K, Norashareena M S, Abdah M A. Antioxidant and Cytotoxicity Effect of Rice Bran Phytic Acid as an Anticancer Agent on Ovarian, Breast and Liver Cancer Cell Lines. Malaysian Journal of Nutrition 2011, 17 (3): $367-$ 75. PMID: 22655458.

[19] Grases F, Isern B, Sanchis P, Perello J, Torres JJ, Costa-Bauza A. Phytate acts as an inhibitor in formation of renal calculi. Front Biosci. 2007, 12: 2580-87. DOI: 10.2741/2256.

[20] Nassar R I, Nassar M. Antimicrobial effect of phytic acid on Enterococcus faecalis. Int Arab J Antimicrobial Agents 2016, 6 (4). DOI: http://dx.doi.org/10.3823/796.

[21] Kumar A, Singh A, Sharma A (2015). Comparative Antianxiety Activity Evaluation of Argyreia speciosa Linn.
(Roots), Caesalpinia digyna Rottler (Roots) and Sphaeranthus indicus Linn. (Flowers). IJPSR (2015), Vol. 6, Issue 10 Doi: dx.doi.org/10.13040/IJPSR.0975-8232.6 (10).4226-29.

[22] Ahmed AMA, Sharmen F, Mannan A, Rahman MA (2015). Phytochemical, analgesic, antibacterial, and cytotoxic effects of Alpinianigra (Gaertn.) Burtt leaf extract. J Traditional Complement Med. 2015 Oct; 5 (4): 248-252. Doi: 10.1016/j.jtcme.2014.11.012.

[23] Mazumder A F, Das J, Gogoi H K, Chattopadhaya P, Paul S B (2014). Antimicrobial activity of methanol extract and fractions from Sarcochlamyspulcherrima, Bangladesh journal of pharmacol, 2014, 9, 4-9.

[24] Moncrieffe S, Williams L A D, Reece S, Thompson S, Knight G, Robatham S, Beaufort C (2019). Antimicrobial Activities of Tamarind (Tamarindus indica) Extracts JOURNAL OF PLANT SCIENCE \& RESEARCH Volume 6, Issue1 www.opensciencepublications.com. 